\title{
Gatifloxacin and Iodopovidine preoperatively of phacectomy: Influence on counting bacterial colonies
}

\section{Gatifloxacino e iodopovidine no pré-operatório de facectomia: influência na contagem de colônias bacterianas}

Verônica Cardoso Santiago', Maria Isabel Lynch Gaete², Rodrigo Pessoa Cavalcanti Lira², Fábio Coelho Alves Silveira ${ }^{3}$, Leonardo Antônio de Souza Bezerra ${ }^{4}$, Maria de Fatima Alves Diniz ${ }^{5}$, Liliane Lima Melo ${ }^{6}$, Célia Maria Machado Barbosa de Castro ${ }^{4}$

\begin{abstract}
Objective: To analyze two methods of reducing conjunctivalmicrobiota in patients undergoing cataract surgery. Methods: A clinical trial with a convenience sample of 57 patients diagnosed with senile cataract (57 eyes) who underwent phacoemulsification with intraocular lens implantation in Recife from 2011 to 2013. Patients were divided into two groups: ATB (27 eyes) in which was instilled antibiotic eye drops (gatifloxacin $0.3 \%$ ) and ASS (30 eyes) with antiseptic eye drops (iodopovidine 5\%); both medications were instilled three times (one drop every 20 minutes, an hour prior to surgery). The groups were evaluated from two collections of conjunctival material: first before instilling some eye drops and the second one immediately after surgery. Gram stain, culture and sensitivity were performed. Results: Comparing the reduction in the number of bacteria found in the slides in the pre-and postoperative, there was no statistically significant difference in both groups. Conclusion: Both use of antiseptic or antibiotic, used as prophylaxis forendophthalmitis, can reduce the conjunctivalmicrobiota.
\end{abstract}

Keywords: Endphthalmitis; Antibiotic prophylaxis; Conjunctiva/microbiology

\section{RESUMO}

Objetivo: Analisar dois método de redução da microbiota conjuntival em indivíduos submetidos à facectomia. Métodos: Ensaio clínico, com amostra de conveniência de 57 pacientes, com diagnóstico de catarata senil (57 olhos), submetidos à facoemulsificação com implante de lente intraocular em Recife entre 2011 a 2013. Os pacientes foram alocados em dois grupos: ATB (27 olhos) no qual foi instilado colírio antibiótico (gatifloxacino a 0,3\%) e ASS (30 olhos) colírio antisséptico (iodopovidine a 5\%), ambas as medicações foram instiladas três vezes (uma gota a cada 20 minutos, uma hora previamente à cirurgia). Os grupos foram avaliados a partir de duas coletas de material conjuntival: a primeira antes de instilar algum colírio e a segunda imediatamente após a cirurgia.Foi realizada bacterioscopia, cultura e antibiograma. Resultados: Comparando-se a redução no número de bactérias encontrado nas lâminas no pré e pós-operatório, não se verificou diferença estatística significativa nos dois grupos. Conclusão: Tanto o uso do antisséptico como do antibiótico usados como profiláticos para a endoftalmite reduzem a microbiota conjuntival

Descritores: Endoftalmite; Antibioticoprofilaxia; Túnica conjuntiva/microbiologia

\footnotetext{
${ }^{1}$ Postgraduate Programme in Surgery, Health Sciences Centre, Federal University of Pernambuco, Recife/PE, Brazil.

${ }^{2}$ Department of Surgery, Health Sciences Centre, Federal University of Pernambuco, Recife/PE, Brazil.

${ }^{3}$ University Hospital, Federal University of Pernambuco, Recife/PE, Brazil.

${ }^{4}$ Contact Lenses Unit, University Hospital, Federal University of Pernambuco, Recife/PE, Brazil.

${ }^{5}$ Laboratory of Microbiology and Immunology of LIKA, Federal University of Pernambuco, Recife/PE, Brazil.

${ }^{6}$ Postgraduate Programme in Applied Biology, Federal University of Pernambuco, Recife/PE, Brazil.
}

The authors declare no conflict of interest

Recebido para publicação em 2/9/2014 - Aceito para publicação em 21/10/2014 


\section{INTRODUCTION}

$\mathbf{I}$ nfectious endophthalmitis is an intraocular inflammatory process that can occur after ophthalmic surgery; it produces disastrous visual results, often leading to blindness or significant visual impairment. ${ }^{(1-9)}$ Studies have shown that in patients with intraocular infection, $82 \%$ of the bacteria found in the vitreous were genetically indistinguishable from those found in the conjunctiva, eyelids, and nose, stressing the importance of the bacterial flora present in the eyelashes in the aetiology of intraocular infection. ${ }^{(3,10)}$

Although antibiotic prophylaxis can reduce the conjunctival flora, studies have shown that fourth-generation antibiotics in the prophylaxis of cataract surgery do not lead to a greater reduction in the incidence of postoperative endophthalmitis. ${ }^{(5,6)}$

This study aimed to assess bacterial colony counts in the ocular conjunctiva of patients undergoing phacoemulsification with prior topical gatifloxacin $0.3 \%$ or povidone-iodine $5 \%$.

\section{Methods}

This was a non-randomised clinical trial with a convenience sample of 57 patients aged 60-69 years with a previous diagnosis of senile cataract who were candidates to phacoemulsification with intraocular lens implantation (PHACO + IOL).

The study was conducted in the city of Recife, Brazil, from 2011 to 2013, after approval by the Research Ethics Committee (under No.342/2009), and was submitted to the Brazilian Clinical Trials Registry (UTN 1111-11573653). All study subjects provided their free and informed consent. The exclusion criteria were patients with ocular disease (glaucoma, conjunctivitis, corneal conditions, entropion, ectropion, blepharitis), patients using topical ocular medication, and patients diagnosed with systemic diseases (such as diabetes mellitus and high blood pressure).

Patients were divided into two groups: the ATB group (27 eyes) used antibiotic eye drops (gatifloxacin $0.3 \%$ ), and the ASS group (30 eyes) used antiseptic eye drops (povidone-iodine 5\%). In both groups, two samples for each patient were collected from the lower conjunctiva with a sterile swab. The first sample was collected preoperatively (immediately before using the eye drops), and the second was collected in the immediate postoperative period (before placing the occlusive dressing). The eye drops were instilled in both groups at a rate of one drop every 20 minutes, for a total of three applications, starting one hour before surgery.

A swab was used to collect the contents of the inferior conjunctival fornix. The patient was asked to look up; the researcher then everted the lower eyelid with one hand and used the other hand to collect the material by rotating and sliding the swab on the inferior conjunctival fornix in both the medial-tolateral and lateral-to-medial directions, without touching the eyelid margins or eyelashes.

For bacterioscopy, sterile normal saline, sterile swabs, slides, and ethyl alcohol $70 \%$ (for cleaning the slides) were used. The swabs were rolled on the glass slides for optical microscopy.

For culture, sterile normal saline, sterile swabs, and a sterile tube containing brain-heart infusion (BHI) medium were used (Figure 1). A blood agar plate was used for cultivating the bacteria. The sample material was rolled on a Petri dish with solid culture medium and was then spread onto the plate in parallel

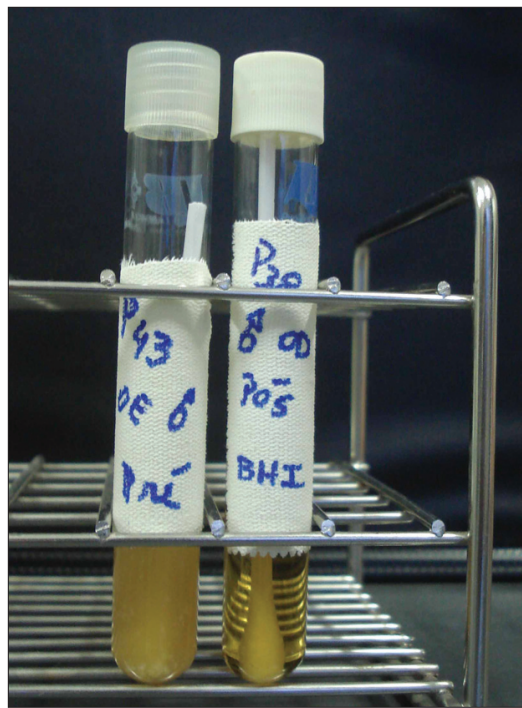

Figure 1:

Preoperative (cloudy) and postoperative (clear) culture tubes

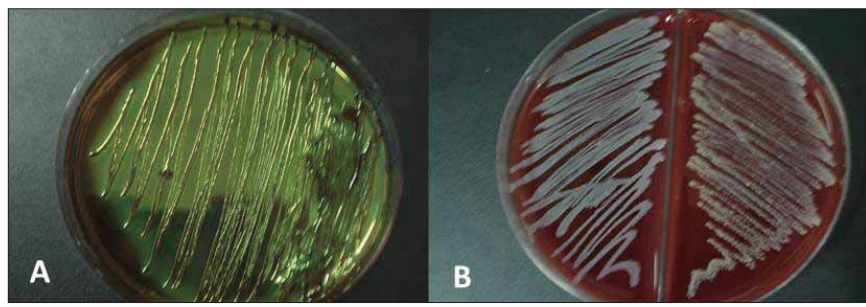

Figure 2, $\mathbf{A}$ and B: Petri dish with a solid culture medium (parallel lines covering the entire surface)

lines over the entire surface of the medium (Figure 2) using a platinum loop. This procedure allowed colonies to grow separately. Subsequently, the plates were incubated at $36^{\circ} \mathrm{C} \pm 1^{\circ} \mathrm{C}$ for 24 to 48 hours; in case of a positive culture, an antibiogram was performed. Discs with gatifloxacin, vancomycin, chloramphenicol, penicillin, erythromycin, oxacycline, gentamicin, ciprofloxacin, ceftriaxone, amikacin, tobramycin, and novobiocin were used for the antibiogram

Statistical analysis was performed using the Statistical Package for the Social Sciences (SPSS) software version 18.0 for Windows.

\section{RESULTS}

\section{Descriptive analysis}

This study included 57 eyes from 57 patients who used medication in the preoperative period of cataract surgery. There were no significant differences between groups regarding age, gender, or eye. (Table 1)

\section{Comparative analysis}

There were no statistically-significant effects for the interaction between Group and Time ( $p=0.263)$; thus, the group effect (together for pre- and postoperative time points) and the time effect (together for both groups) were assessed. Está estranha/pouco clara ou redudante essa afirmação. In the analysis of variance, there were no significant differences between groups, regardless of the time point $(\mathrm{p}=0.654)$. When comparing the 
Table 1

\section{Demographic data}

\begin{tabular}{lccc}
\hline Variable & \multicolumn{2}{c}{ Intervention } & p-value \\
\cline { 2 - 3 } & ATB (n= 27) & ASS (n= 30) & \\
\hline $\begin{array}{l}\text { Gender n (\%) } \\
\quad \begin{array}{l}\text { Female } \\
\text { Male }\end{array}\end{array}$ & $15(55.6)$ & $17(56.7)$ & \\
$\begin{array}{l}\text { Age } \\
\quad \text { Mean (SD) }\end{array}$ & $12(44.4)$ & $13(43.3)$ & 0.933 \\
$\begin{array}{l}\text { Eye n (\%) } \\
\quad \text { Right }\end{array}$ & $67.8(8.5)$ & $70.2(7.7)$ & 0.277 \\
Left & $13(48.1)$ & $14(46.7)$ & \\
\hline
\end{tabular}

$\mathrm{ATB}=$ Antibiotic, $\mathrm{ASS}=$ Antiseptic, $\mathrm{SD}=$ Standard Deviation

Table 2

Mean and standard error for the number of bacteria in
the slides containing material sampled pre- and
postoperatively, according to the type of intervention

\begin{tabular}{lcc}
\hline Intervention & \multicolumn{2}{c}{ Time Point } \\
\cline { 2 - 3 } & Preoperative & Postoperative \\
\hline ATB & $3.0(1.9)$ & $2.1(1.6)$ \\
ASS & $2.7(1.4)$ & $2.2(1.2)$ \\
\hline
\end{tabular}

$\mathrm{ATB}=$ Antibiotic, ASS $=$ Antiseptic

Table 3

Positive pre- and postoperative culture results according to the type of intervention

\begin{tabular}{lcc}
\hline Intervention & \multicolumn{2}{c}{ Positive culture } \\
\cline { 2 - 3 } & $\begin{array}{c}\text { Preoperative } \\
\mathbf{n}(\%)\end{array}$ & $\begin{array}{c}\text { Postoperative } \\
\mathbf{n}(\%)\end{array}$ \\
\hline ATB $(\mathrm{n}=27)$ & $20(74,1)$ & $16(59,3)$ \\
ASS $(\mathrm{n}=30)$ & $25(83,3)$ & $14(46,7)$ \\
\hline
\end{tabular}

ATB = Antibiotic, ASS = Antiseptic

pre- and postoperative time points, a statistically-significant reduction $(p=0.001)$ was observed in both groups. Thus, both groups showed a similar behaviour in relation to the number of bacteria, which decreased postoperatively, as seen in Table 2 .

The culture variable (positive $\mathrm{x}$ negative), which is a qualitative variable, was analysed by means of a generalised estimating equation (GEE) model, using the logit function as the binding function, because the binomial distribution was used. This analysis evaluated the group effect, the time effect, and the effects of the group-time interaction. In this case, the interaction was statistically significant $(\mathrm{p}<0.05)$, indicating that the differences between groups were time-dependent, or that time differences were group-dependent. Thus, the group effect for each time point was assessed separately, and the time effect for each group was assessed separately.

As regards the effect of the tested eye drops, no statistically-significant differences were found between groups both in the preoperative $(\mathrm{p}=0.492)$ and post-operative cultures $(\mathrm{p}=0.439)$. In the ASS group there was a statistically-significant reduction in positive cultures from the pre- to the postoperative period $(\mathrm{p}=0.006)$, but this effect was not observed in the ATB group $(\mathrm{p}=0.258)$ (Table 3$)$.

\section{DiscusSION}

Cataract surgery is a procedure with great social value, as it promotes visual rehabilitation and improves the quality of life of patients by increasing their self-esteem and allowing them to resume their daily activities and their independent living. ${ }^{(11,12)}$ Studies show that personal beliefs, such as the "fear of going blind," "fear of dying during surgery," "fear of pain," and "fear of anaesthesia," added to the lack of knowledge about the surgical procedure and its complications, lead to a delay in the demand for cataract surgery. ${ }^{(11,12)}$ The complication most feared by surgeons is endophthalmitis, which can lead to poor visual results and even vision loss. ${ }^{(1-9)}$

Considering that senile cataract is the leading cause of blindness worldwide ${ }^{(13-15)}$ and the growing elderly population, outpatient procedures are an important tool in ophthalmology.

Cataract surgery with IOL implantation using manual extracapsular cataract extraction (ECCE) and PHACO are safe and widely-used outpatient procedures due to benefits such as avoiding the need for hospitalisation, a shorter hospital stay, and, particularly with the advent of PHACO, the use of topical anaesthesia (eye drops), a smaller incision for IOL implantation, a lower rate of intra- and postoperative complications, earlier visual recovery, and therefore fewer postoperative visits. ${ }^{(16,17)}$

All these benefits provide security and comfort to physicians and their staff, as well as to patients and their families, providing a return to normal, independent life while minimising operational costs; this is important because in Brazil a large number of patients undergo surgery in public hospitals managed by the Brazilian Unified Health System (SUS), which depends on Federal Government funding, as shown in a study by KaraJúnior et al. ${ }^{(17)}$

Preoperative care includes a detailed examination of the ocular surface, adequate surgical indication, sterilisation of surgical instruments or use of disposable instruments, and ocular instillation of antimicrobial agents such as antibiotics and/or antiseptics.

In the present study, prophylaxis with antibiotics and antiseptics in the preoperative period of cataract surgery produced a decrease in bacterial colony counts in the ocular conjunctiva, corroborating the findings in the literature. ${ }^{(18)}$ There was a reduction in bacterial colony counts on bacterioscopy in the pre- and postoperative periods both in the group that used gatifloxacin $0.3 \%$ antibiotic eye drops and the group that used povidone-iodine $5 \%$; the difference between groups was not statistically significant ( $\mathrm{p}=0.492$ in the pre- and $\mathrm{p}=0.439$ in the postoperative period), showing that both medications can reduce the ocular conjunctival microbiota.

As regards time points (pre- vs. postoperative), there was a greater reduction in the number of bacterial colony counts in the group that used the antiseptic agent $(p=0.006)$ than in the group that used the antibiotic agent $(p=0.258)$; this is probably 
due to the fact that the average operating time for cataract surgery is 30 to 45 minutes, and the time required for the antibiotic agent to achieve its minimum inhibitory concentration is greater than the action time of the antiseptic agent.

Gram-positive cocci were the most commonly found pathogens (with Staphylococcus being the most common), followed by Gram-positive bacilli. Other agents were: $S$. saprophyticus, Citrobacter ferundii, Enterococcus, Streptococcus (Viridans group), E. coli, Serratia liquefaciens, and Corynebacterium sp., all of which have already been described in several studies assessing the ocular conjunctival flora. ${ }^{(19-22)}$

The antimicrobial agents to which pathogens were most susceptible were gatifloxacin, vancomycin, tobramycin, and oxacycline, in agreement with the literature. ${ }^{(4,5)}$ It is important to use these agents, as studies show that $82 \%$ of the bacteria isolated in postoperative endophthalmitis are genetically identical those isolated from the eyelid and conjunctiva of patients. ${ }^{(1)}$ Knowing the conjunctival flora and its drug-sensitivity is important when choosing postoperative antibiotics, which should have a broad spectrum, high bactericidal power, fast action, appropriate bioavailability, and low toxicity in order to minimise the likelihood of resistance and optimise treatment, reducing the need for longer periods of administration.

Many ophthalmologists recommend using pre- and postoperative antimicrobial agents, but there is no consensus around this practice, which is seen as controversial by many. ${ }^{(6,7)}$

In the present study, all patients who received preoperative prophylaxis with antibiotic or antiseptic agents were instructed to instil antibiotics postoperatively; there is consensus around this measure among ophthalmologists and it is widely recommended in the literature, ${ }^{(5,6)}$ although there are no studies specifying which antibiotic agent and which dose would be most appropriate. ${ }^{(5,6,20)}$

There were no cases of endophthalmitis in this study, regardless of the preoperative antimicrobial agent, as this disease has a low incidence $(0.07-0.267 \%)$, affecting roughly one in 15,000 patients; therefore, larger studies would be required to study this disease.

The limitations of this study include the small number of eligible patients $(n=60)$ considering the inclusion criteria and the difficulty in studying patients for a longer follow-up period, with repeated conjunctival sampling. Furthermore, the mechanical effect of the procedure itself (such as the use of irrigation solutions during surgery) cannot be discarded, as this study did not have a control group without medication.

Nevertheless, this study confirmed that both antiseptic and antibiotic eye drops used in the prophylaxis of endophthalmitis can reduce the conjunctival microbiota and may be useful as supporting measures for preventing endophthalmitis.

\section{REFERENCES}

1. Isenberg S, Apt L, Yoshimori R, Khwarg S. Chemical preparation of the eye in ophthalmic surgery. Comparison of povidine-iodine on the conjunctiva with a prophylactic antibiotic. Arch Ophthalmol. 1985;103(9):1340-2.

2. Barza M, Pavan PR, Doft BH, Wisniewski SR, Wilson LA, Han DP, et al. Evaluation of microbiological diagnostic techniques in postoperative endophthalmitis in the Endophthalmitis Vitrectomy Study. Arch Ophthalmol. 1997;115(9):1142-50.
3. Aaberg TM, Flynn HW, Schiffman J, Newton J. Nosocomial acute-onset postoperative endophthalmitis survey. A 10-year reviewofincidenceandoutcomes. Ophthalmology. 1998;105(6):1004-10.

4. Taban M,Behrens A, Newcomb RL, Nobe MY, Saedi G, Sweet PM, et al. Acute endophthalmitis following cataract surgery: a systematic review of the literature. Arch Ophthalmol. 2005;123(5):613-20.

5. Deramo VA, Lai JC, Fastenberg DM, Udell IJ. Acute endophthalmitis in eyes treated prophylactically with gatifloxacin and moxifloxacin Am J Ophthalmol. 2006;142(5):721-5

6. Morhirfar M, Feiz V, Vitale AT, Wegelin JA, Basavanthappa S, Wolsey DH. Endophthalmitis after uncomplicated cataract surgery with the use of fourth generation fluoroquinolones: a retrospective observational case serie. Ophthalmology. 2007;114(4):686-91.

7. Lloyd JC, Braga-Mele R. Incidence of postoperative endophthalmitis in a high-volume cataract surgicentre in Canada. Can J Ophthalmol. 2009;44(3):288-92.

8. Results of the Endophthalmitis Vitrectomy Study. A randomized trial of immediate vitrectomy and of intravenous antibiotics for the treatment of postoperative bacterial endophthalmitis. Arch Ophthalmol 1995;113(12):1479-96.

9. Krause L, Bechrakis NE, Heimann H, Kildal D, Foerster MH. Incidence and outcome of endophthalmitis over a 13-year period. Can J Ophthalmol. 2009;44(1):88-94.

10. Speaker MG, Milch FA, Shah MK, Eisner W, Kreiswirth BN. Role of external bacterial flora in the pathogenesis of acute postoperative endophthalmitis. Ophthalmology. 1991;98(5):639-49.

11. Marback R, Temporini E, Kara Júnior N. Emotional factors prior to cataract surgery. Clinics (São Paulo). 2007; 62(4):433-8.

12. Temporini ER,Kara N Jr,Jose NK,Holzchuh N. Popular beliefs regarding the treatment of senile cataract. Rev Saúde Pública. 2002; 36(3):343-9.

13. Gillies M, Brian G, La Nauze J, Le Mesurier R, Moran D, Taylor H, Ruit S. Modern surgery for global cataract blindness: preliminary considerations. Ach Ophthalmol. 1998;116(1):90-2.Review.

14. Kara-José N, Cursino M, Whitaker E. Cirurgia de catarata: otimização de centro cirúrgico com utilização de pacote cirúrgico pré-montado. Arq Bras Oftalmol. 2004;67(2):305-9.

15. Kara-José N, Temporini ER. Catarata e cegueira: epidemiologia e prevenção. In: Arieta CE, editor. Cristalino e catarata. Rio de Janeiro: Cultura Médica; 2002.p.49-56.

16. Kara-Júnior N, Avakian A, Lower LM, Rocha AM, Cursino M, Alves MR. Facoemulsificação versus extração manual do cristalino: análise de custos. Arq Bras Oftalmol. 2004;67(3):481-9.

17. Kara-Júnior N, Espínola RF. Evolução e viabilização de um centro cirúrgico ambulatorial para cirurgias de catarata em larga escala em um hospital universitário. Arq Bras Oftalmol. 2010; 73(6):494-6

18. ESCRS Guidelines for Prevention and Treatment of Endophthalmitis Following Cataract Surgery: Data, Dilemmas and Conclusions; 2013.

19. Höfling-Lima AL, Farah ME, Montenegro L, Alvarenga LS, Chalita MRC, You MCZ. Alterações da microbiota conjuntival e palpebral após uso tópico de lomefloxacina e tobramicina na cirurgia de catarata e cirurgia refrativa. Arq Bras Oftalmol. 2002; 65(1):21-9.

20. Miño de Kaspar H, Chang RT, Singh K, Egbert PR, Shriver EM Blumenkranz MS,. Antibiotic resistance patterns of ocular bacterial flora: a prospective study of patients undergoing anterior segment surgery. Ophthalmology. 2003; 110(10):1946-51.

21. Oliveira RCS, Brasil OFM, Arantes RS, et al. Eficácia de um regime de administração de antibióticos tópicos na redução da microbiota conjuntival de pacientes sadios com catarata senil. Rev Bras Oftalmol. 2007;66(4):242-7.

22. Arantes TEF, Castro CMMB, Cavalcanti RF. Flora bacteriana conjuntival após uso tópico de ciprofloxacino e gatiflocacino em cirurgia de catarata. Arq Bras Oftalmol. 2008;71(2):191-6.

\section{Corresponding author:}

Verônica Cardoso Santiago

Rua Deputado Souto Filho, 108, Térreo

Bairro Maurício de Nassau, Caruaru/PE, Brazil

CEP.: 55.012-31

E-mail:vecasantiago@hotmail.com 